\title{
Proposing Notaries' Deed Digitalization in Indonesia: A Legal Perspective
}

\author{
Ika Yuli Agustin \\ Narotama University, Indonesia \\ Ghansham Anand \\ Airlangga University, Indonesia
}

\begin{abstract}
Along with emerging technology, a notary public's role should adjust this changing development, mainly dealing with a deed. Technological development inevitably impacts the role of a notary public and the future digitization of notarial deeds. To date, notaries in Indonesia remain implementing laws and regulations that have not been changed. In contrast, technological development has shifted rapidly, especially on the notaries' task in appearing, reading, signing, and using stamps. This study aimed to identify the challenges of implementing notaries' deed digitalization by taking into account rapid technological development. With legal research, this study showed that as a consequence of technological development, notarial functions' disruption in Indonesia evoked a concept of a cyber notary, an idea of notarial function through an online system. As it has flourished globally, digital disruptions had brought out an electronic system that changed the implementation of works, business, professions, and functions, mainly to notarial functions. Nevertheless, no specific rules were established to amend Notary Law 02/2014, particularly to the requisites of authentic deeds by a cyber notary. Indonesia applied some restrictions on technology to maintain the legality of authentic deeds to place the notarial profession as a public official consistently.
\end{abstract}

KEYWORDS: Indonesian Notaries, Technological Development, Deed Digitalization.

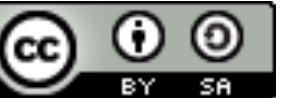

Copyright (C) 2021 by Author(s)

This work is licensed under a Creative Commons Attribution-ShareAlike 4.0 International License. All writings published in this journal are personal views of the authors and do not represent the views of this journal and the author's affiliated institutions.

\section{HOW TO CITE:}

Agustin, Ika Yuli \& Ghansam Anand, "Proposing Notaries' Deed Digitalization in Indonesia: Legal Perspective" (2021) 8:1 Lentera Hukum 49-72. DOI: <https://doi.org/10.19184/ejlh. v8i1.21375>.

Submitted: 15/12/2020 Reviewed: 21/12/2020 Revised: 05/04/2021 Accepted: 07/04/2021

\footnotetext{
* Corresponding author's e-mail: ikayuliagustin01@yahoo.com
} 


\section{INTRODUCTION}

To date, Indonesia remains to refer to the Civil Code concerning authentic deeds. The Civil Code is regarded as conventional by considering technological development that gradually affects notarial functions through authentic deeds' digitalization. Article 1868 of the Civil Code mentions that a notary should do an authentic deed without being facilitated by law through as electronic-based transactions. On the other hand, Article 5(4) of the Electronic Information and Transactions Law 19/2016 amended from Law 11/2008 (ITE Law) mentions that electronic-based information and documents should be established in the form of authentic written deeds by a notary. Thus, the use of digital-based deeds may be arduous in some cases, such as the deed in an online credit application. In addition to establishing relaas and partij deeds ${ }^{1}$ as Indonesia's notaries implement through methods and procedures, notaries in Japan are authorized to establish digital-based deeds. ${ }^{2}$ The Netherlands regulated the same as the consequence of the European Union's Directive 1999/93/EC. ${ }^{3}$ Also, the United States has already begun to use electronic-based signatures. ${ }^{4}$

In Indonesia, studies on the intersection of notarial functions and deed digitalization through the lens of technological development are considerably rare. Most studies discussed the legality of electronic deeds and the emergence of a cyber notary. For instance, the study made by Naily

1 Relaas deed is a form of the deed made for evidence by the party. The deed is described authentically as a situation seen or witnessed by a notary. A deed made is based on what is seen and witnessed by the notary. GHS. Lumban Tobing, Peraturan Jabatan Notaris (Jakarta: Erlangga, 1991) at 51. Partij deed based on the information explained and told the notary to state the information in a notarial deed. Therefore, the deed was done before a notary. Herlien Budiono, Dasar Teknik Pembuatan Akta Notaris (Bandung: Citra Aditya Bakti, 2017) at 7.

2 Global regulation, "Ordinance for Enforcement of the Notary Act", online: $<$ https://www.global-regulation.com/law/japan/277686/ordinance-for-enforcementof-the-notary-act.html>.

3 The Netherlands Government, "Richtlijnen elektronische handtekeningen 1999" in English "The Electronic Signatures Directive 1999/93/EC" was a European Union directive on the use of electronic signatures (e-signatures) in electronic contracts within the European Union.

4 Herlien Budiono, Kumpulan Tulisan Hukum Perdata di Bidang Kenotariatan (Bandung: Citra Aditya Bakti, 2008) at 221. 
Zahrotun's publication concluded that deed authenticity referred to civil law in Dutch and Indonesia, which included the legality and mechanism of maintaining electronic-based original deed in Indonesia and the use of electronic-based original deed in the courts. ${ }^{5}$ Another study discussed the conflict between Articles 15(3) and 16(1) of the Notary Law 02/2014. ${ }^{6}$ This study concluded that the certification of transactions through a cyber notary was considered valid as an authentic deed.

This study aimed to identify the challenges of implementing notaries' deed digitalization by taking into account rapid technological development. As it has flourished globally, digital disruptions had brought out an electronic system that changed the way to work, including in implementing notarial functions. Then, this study has two sections. The first section discusses the disruptions of notarial functions against technological development, as a dramatic change from offline to online-based challenges prospective notaries in Indonesia. The second section discusses the possibility of applying deed digitalization by considering the rapid information technology through electronic-based public services.

\section{METHODS}

This study was legal research that aimed to find laws and regulations, legal principles, and doctrines to address current legal issues. ${ }^{7}$ It aimed to figure out the coherence between laws and norms, whether any norms are coherent to legal principles, and whether one's behavior is coherent to legal norms or principles. ${ }^{8}$ In so doing, this study used statutory and comparative approaches, carried out by reviewing all laws and regulations with further relevant comparisons related to the legal issues.

5 Naily Zahrotun Nisa', “Aspek Legalitas Penyimpanan Minuta Akta Notaris Secara Elektronik" (2020) 5:2 Jurnal Civic Hukum.

6 Zainatun Rossalina, Moh Bakri, Itta Andrijani, "Keabsahan Akta Notaris Yang Menggunakan Cyber Notary Sebagai Akta Otentik" (2016) Magister Ilmu Hukum dan Kenotariatan.

7 Peter Mahmud Marzuki, Penelitian Hukum (Jakarta: Kencana Prenada Media Group, 2011) at 35.

8 Ibid at 47. 


\section{A NOTARY AND TECHNOLOGICAL DEVELOPMENT}

The term notary is derived from the word notarius in singular and notarii in plural. Notarius is a term used by the Romans to name those who did the work of writing. ${ }^{9}$ In Article 1865 of the Civil Code that everyone who claims to have the right must prove the existence of such rights. The written evidence tool above is a series of letters and words into sentences and containing meanings. In Indonesia, known as 'acte,' or written 'akta.' ${ }^{10}$ A notary is an authorized public official that establishes authentic deeds as long as it is not exclusively for other public officials. Indonesian law requires some authentic deeds to be established to improve their legal assurance, order, and protection. Besides, the concerned parties also need them to make sure their rights and liabilities, particularly for the sake of their legal assurance, order, and protection, and generally for public society. A notary must follow laws and regulations to assist and serve people who need authentic written evidence on legal situations, events, or actions. This purpose requires every notary to have a passion for serving people. ${ }^{11}$ The Notary Law defines a notary as an authorized public official who establishes authentic deeds and holds other authorities based on the Notary Law and other relevant legislation. This definition refers to notarial authority and functions as a public official who can establish authentic deeds and other authorities mentioned in the Notary Law. ${ }^{12}$ Thus, the notary as a public official has authority in implementing office duties against the current disruptions.

The public officials specified in Article 1868 of the Civil Code have not been clearly and completely outlined. Article 1(1) of the Notary Law stated that the notary is the only public official to do an authentic deed related to all acts, agreements, and determinations required by general regulations or

9 Abdul Ghofur Anshori, Lembaga Kenotariatan Indonesia Perspektif Hukum dan Etika (Yogyakarta: UII Press, 2016).

10 A.A.Andi Prajitno, Seri A Kewenangan Notaris dan Contoh Bentuk Akta (Perwira Media Nusantara, 2018).

11 Wijanarko Fahma Rahman, "Tinjauan Yuridis Akta Notaris Terhadap Pemberlakuan Cyber Notary Di Indonesia Menurut Undang-Undang Nomor 2 Tabun 2004" (2015) 2:2 Jurnal Repertorium at 8.

12 Abdul Ghofur Anshori, supra note 9. 
the interested declared in an authentic deed, guarantee the certainty of the date of doing the deed, keep the deed minuta, ${ }^{13}$ provide grosse deed, ${ }^{14}$ copy and quotation of the deed as long as the deed is not assigned or excluded to officials by the legislation. ${ }^{15}$ According to Soegondo Notodisoerjo, a public official is appointed and dismissed by the government and given authority and obligation to serve the public in some issues because of participating in implementing the government's powers. Notaries' position is knotted as a trait and characteristic that distinguishes it from other positions. ${ }^{16}$ Thus, the notary public must act professionally in carrying out their position according to the standard of office determined by the Notary Law, namely to provide good service to the community.

The role of a notary aims to create a civil legal relationship between legal subjects. It refers to public officials that people and government trust to assist and serve legal assurance, order, and protection through authentic deeds established by or in front of them. An authentic deed is perfect evidence with crucial legal value in a legal interaction among public society. ${ }^{17}$ The evidentiary of legal certainty, including the rights and obligations of a person, requires a notary role. The notary public's role in providing legal certainty and legal protection for the community is crucial. This role is more preventive by doing an authentic deed related to the legal status, rights, and obligations of a person in law that serves as the perfect evidence in court that is in the event of a dispute of rights and obligations. ${ }^{18}$ With the theory of legal protection, legal counseling provided by a notary

13 Deed minuta is the original deed that lists the signatures of the confronters, witnesses, and notaries kept as part of the notary protocols. See the Notary Law.

${ }^{14}$ Grosse deed is one of the deed copies for recognizing debts with the head of the deed "Demi Keadilan Berdasarkan Ketuhanan Yang Maha Esa," in English: "For Justice Based on One Almighty God," which has the power of executorial. See the Notary Law.

15 Lumbuan Tobing, Peraturan Jabatan Notaris (Jakarta: Erlangga, 1983) at 30.

16 Sjaifurrachman, Aspek Pertanggungjawaban Notaris dalam pembuatan Akta (Bandung: Mandar Maju, 2011) at 5.

17 Ratih Tri Jayanati, "Perlindungan Hukum Notaris dalam Kaitannya dengan Akta Yang Dibuatnya Manakala Ada Sengketa di Pengadilan Negeri” (2020) Thesis, Universitas Diponegoro.

18 Habib Adjie, Aspek Pertanggungjawaban Notaris dalam Pembuatan Akta (Bandung: Mandar Maju, 2011) at 7-8. 
public to the public who make an authentic deed is a form of protection by a notary public. Authentic deed made later does not occur mistakes in the future does not harm the community.

To be sure, the notarial deed remains playing an essential role in ensuring legal certainty because of its authentic nature. In practice, it becomes a complete evidentiary tool in case of problems related to the deed. The need for authentic deed as proof increases and improves business relationships in various business fields, from local to international. ${ }^{19}$ The notary authority in its duties and positions is to do an authentic deed. The form of notarial deed is outlined in Article 38 of the Notary Law. A notarial deed is an authentic deed during the deed fulfilling the elements in Article 15(1) of the Notary Law. In addition to fulfilling the details contained in Article 15(1) of the Notary Law, the notarial deed made must also meet the elements of the validity of an agreement as contained in Article 1320 of the Civil Code. This authentic deed is one type of proof tool as the type of evidence tool stipulated in Article 1866 of the Civil Code. The meaning of an authentic deed has a perfect evidentiary force. It can also be determined that anyone is bound by the deed, as long as it cannot be proven evidence otherwise based on a court ruling with a fixed legal force. ${ }^{20}$ The development of the function and role of a notary public, especially about the creation of authentic deed, has demanded the notary to be able to use the concept of the implementation of positions following the development of information and communication technology in order to create a fast, precise, and efficient service.

Currently, information and communication technology is inevitable. This technology plays an essential role and contributes to economic, social, and cultural development. Information and communication technology may also affect the future's social condition, such as medical services, education,

19 Ibid at 8 .

${ }^{20}$ Habib Adjie, Kebatalan dan Pembatalan Akta Notaris (Refika Aditama: Bandung, 2015). 
governmental administration, and other aspects of life. ${ }^{21}$ To be sure, technology has become for many people in carrying out daily activities. Indonesia has 50 percent of citizens who have already used the internet. Consequently, a global information network is formed to connect communication between one party and another without any restrictions on space and time. ${ }^{22}$ It allows people to learn technology and use technology to the fullest, such as interacting with others, obtaining information to apply it in their daily activities.

Historically, science and technology have played crucial roles, particularly in the economic sector. It supports transformations and evokes industrial revolution 4.0. Hannover Fair was one who first introduced industrial terminology 4.0 in 2011 in Germany before it turned into Industry 4.0. Industrial terminology 4.0 was a name for the German government's technology strategy to be ready for 2020. ${ }^{23}$ Dortmund University's research considered those concepts as the component of Industry 4.0, such as Cyber-Physical System (CPS), Internet of Things (IoT), Internet of Services (IoS), Smart Factory. This research defined Industry 4.0 as follows:

"Industry 4.0 is a collective term for technologies and concepts of value chain organization. Within the modular structured Smart Factories of Industry 4.0, CPS monitors physical processes, creates a virtual copy of the physical world, and makes decentralized decisions. Over the IoT, CPS communicates and cooperates and humans in realtime. Via the IoS, both internal and cross-organizational services are offered and utilized by participants of the value chain." ${ }^{24}$

${ }^{21}$ Meriam Darus Badrulzaman, "Mendambakam Kelabiran Hukum Saiber (Cyber Law) di Indonesia" Speech of Professorship Retirement (Medan: Universitas Sumatera Utara, 2007) at 6.

22 M. Rustam, "Internet dan Penggunaannya ((Survei di Kalangan Masyarakat Kabupaten Takalar Provinsi Sulawesi Selatan" (2017) Jurnal Studi Komunikasi dan Media at 1324.

${ }^{23}$ Busyra Azheri, "Tantangan Pendidikan Kenotariatan di Era Revolusi Industri 4.0" (2019) Magister Kenotariatan, Universitas Sumatera Utara.

${ }^{24}$ Bambang Pratama, "Perubahan Dan Tantangan Hukum Menghadapi Industri 4.0" (2018), online: <https://business-law.binus.ac.id/2018/07/07/perubahan-dantantangan-hukum-menghadapi-industri-4-0/>. 
Thus, Industry 4.0 is a collective term for continual technology and the concept of organization's values, starting from conducting physical processes, making a virtual copy of the physical world, and making a decentralized decision. The pattern of communication and cooperation, among others, should be real-time.

In this context, prospective notaries should be familiar with information for their future tasks, such as land registration, certificate checking, and onlinebased assurance rights. In registering land, the Ministry of Agrarian and Spatial Affairs/Department of National Land establishes the electronicbased registration even if this registration process is not fully implemented since the government has not regulated the system yet. Subsequently, the Ministry only established a Circular Letter No. 5/SE-100/1/2015. It aimed to provide public access to land services, improve the quality of public services in the land sector, the integrity and designation of anti-corruption perception, and service and management modernization of agrarian, spatial, and land affairs. ${ }^{25}$ However, notary activities in Indonesia have not been able to use the concept based on electronics because it does not have a strictly legal basis related to it.

Nevertheless, electronic-based notary or cyber notary has been introduced in some countries. A cyber notary refers to implementing notarial functions through information technology, particularly to the establishment of deeds. This current new era makes every system shift from conventional to electronic-based, including notarial functions. It is a concept that utilizes technological advances for notaries in carrying out their daily duties, such as the digitization of documents, electronic signing of the deed, the implementation of General Meeting of Shareholders (GMS) by teleconference, and other similar matters. A cyber notary's benefit is to facilitate transactions between parties who live far away so that distance is not an issue anymore. Overseas shareholders may attend the GMS using teleconference media with other shareholders. ${ }^{26}$ The benefits of a cyber

25 Ibid.

26 Luthvi Febryka Nola, "Peluang Penerapan Cyber Notary dalam Peraturan Perundangundangan di Indonesia” (2011) 2:2 Jurnal Negara Hukum at 78. 
notary are expected to be applied in Indonesia per the current technological developments.

Notaries in Japan (called kooshoonin) have implemented their functions through the electronic system since 2000. Kooshoonin follows Japan's Notarial Function 53/1908, which has several amendments. ${ }^{27}$ In addition to establishing relaas deeds and partij deeds as what Indonesia's notaries implement through methods and procedures they are supposed to follow, Japan's kooshoonin is also authorized to establish digital-based deeds through Electronic Notarial System. It will be saved and managed by the Japan National Notary Association (JNNA), an organization in Japan like Ikatan Notaris Indonesia (INI). ${ }^{28}$ Furthermore, Dutch has already begun to use electronic-based signatures, and it is regulated under richtlijnen elektronische handtekeningen 1999. ${ }^{29}$ The United States has also established the e-signature regulation as the basis of electronic-based signatures, whose legality is equal to a manual one. ${ }^{30}$ This system ensures originality on signatures entrusted in an independent organization called a Trusted Third Party. This organization saves people digital signatures, ensures the truth of data transfer, and saves other data through the orthography method.

This system resulted in pros and cons. The main problem with this system is its disputation about the legality of cyber notary's deeds. Some argue that cyber notary opposes tabellionis officium fideliter exercebo principle; a notary must work traditionally. It is a principle that notaries uphold all this time. It was proposed by the Information Security Committee of the American Bar Association in 1993 for which a notary in the United States could authenticate various electronic-based business communication documents as applied in Florida and Alabama. However, it often experiences rejection by other states related to the deed legality. The notary

27 Irma Devita, "Menyongsong Kongres Notaris International," 2019, online: <https:// irmadevita.com/2019/menyongsong-kongres-international-dunia-notaris/>.

28 Indra Pranajaya, "Studi Komparatif Terhadap jabatan dan kode etik notaris di Indonesia dan Jepang” (2012) Thesis, Universitas Indonesia.

${ }_{29}$ The Netherlands Government, supra note 3.

30 Herlien Budiono, supra note 4 at 221. 
public in the United States has no responsibility regarding the legality of documents. However, the authentic deed that notaries establish in civil law states has perfect argumentation power rather than those in common law state. ${ }^{31}$ Implementing a cyber notary in Indonesia cannot be interpreted as implementing cyber notary in the United States. Instead, Indonesia must be flexible to understand cyber notary because there are differences in the function and authority of the notary public.

\section{THE IMPORTANCE OF NOTARIES' DEED DIGITALIZATION IN INDONESIA}

An Indonesian scholar Sudikno Merto Kusumo argues that a deed is a signed document that contains affairs as the basis of rights or engagement and is intentionally made for evidence. ${ }^{32}$ It is classified into two categories: authentic and private deeds. The authentic deed is scripted evidence established under statutory regulations in front of an authorized public official where the deed is done, referring to Articles 1867 and 1868 of the Civil Code. ${ }^{33}$ The establishment of a notarial deed can be through two mechanisms. First, partij deed or proposer deed refers to a deed established in front of a public official. It contains description or explanation, statements by relevant parties in front of a public official. ${ }^{34}$ Second, relaas deed or official deed refers to a deed established by authorized public officials who explain what they saw and did. The initiative of establishing relaas deed comes from the pertinent official, not from another party whose name is mentioned in that deed. ${ }^{35}$ So the existence of a deed is a formal condition for the existence of legal action.

The notarial deed is absolute scripted evidence or document as it consists of three strengths of evidence. First, physical evidence, making deeds able to

31 Andes Willi Wijaya, "Konsep Dasar Cyber Notary: Keabsahan Akta dalam Bentuk Elektronik" (2018), online: <https://vivajusticia.law.ugm.ac.id/2018/11/29/konsepdasar-cyber-notary-keabsahan-akta-dalam-bentuk-elektronik/>.

32 Daeng Naja, Teknik Pembuatan Akta (Yogyakarta: Pustaka Yustisia, 2012) at 1.

33 Herlien Budiono, supra note 4 at 77.

${ }^{34}$ Abdul Ghofur Anshori, supra note 9 at 22.

35 Ibid. 
prove their legality as authentic deeds. ${ }^{36}$ Second, formal evidence, ensuring that events and facts mentioned in a deed are identified and listened to by a notary and explained by the proposers. Everything mentioned in the deed is under predetermined procedures of deed establishment. ${ }^{37}$ Third, material evidence, providing material assurance of a deed. ${ }^{38}$ The notarial deed must fulfill the three evidentiary powers in order to be a perfect tool of evidence.

Additionally, particular terms should be completed to do a deed established by or in front of a notary to have those three evidence strengths. Those terms, for instance, are mentioned in Articles 22, 24, 25, and 28 of Regulation of Notarial Function (PJN). Then, a deed is considered authentic when those terms have been entirely completed and implemented. Also, notaries solely obligate to record that appropriate parties propose and get interested in. They have no obligation to investigate anything the proposers put forward in their deed materially. ${ }^{39}$ Article 15(1) of the Notary Law mentions that notaries have authority to establish authentic deeds of any actions, contracts, and provisions required by laws or of any interests the concerned parties consider to mention in their authentic deed. They should ensure the deed establishment date, keep the deed safe, and provide the grosse, the copy, and the deed's extract as long as they are authorized to do so unless another party or official is delegated by law. However, Article 15(3) mentions that notaries have another authority regulated by law. What is meant by "another authority regulated by law" includes certifying electronic-based transactions (cyber notary)..$^{40}$ However, notary authority in making certification of transactions conducted electronically does not necessarily make the notary certify transactions conducted electronically because the government has not issued new legislation regulating how it exercises its authority.

${ }^{36}$ Habib Adjie, Hukum Notariat di Indonesia-Tafsiran Tematik Terhadap UU No.30 Tahun 2004 Tentang Jabatan Notaris (Bandung: Refika Aditama, 2008) at 26-27.

37 Ibid.

38 Ibid.

${ }^{39}$ M. Ali Boediarto, Kompilasi Kaidah Hukum Putusan Mahkamah Agung, Hukum Acara Perdata Setengah Abad (Jakarta: Swa Justitia, Jakarta, 2005) at 74.

40 Habib Adjie, Hukum Notaris Indonesia (Jakarta: Refika Aditama, 2007) at 78. 
There is a conflict between Articles 15 and 16(1) of the Notary Law in practice. Article 15 allows the notary public to certify cyber notary transactions. Article 16 extends deed authenticity elements listed in Article 1868 of the Civil Code. A notary public may implement cyber notary, such as implementing the General Meeting of Shareholders of Limited Liability Companies where the deed is voluntary. This is because Article 77 of the Limited Liability Companies Law states that the implementation of the General Meeting of Shareholders (GMS) can be conducted through video conferences or other electronic media facilities that allow all GMS participants to see and hear and directly participate in the meeting. Also, the use of computers in the making of deed and during the process of registration of legal entities online through the website of the Legal Entity Administration System (Sisminbakum) is a sign that notaries in Indonesia have begun to use computer systems and the internet in the implementation of their duties. ${ }^{41}$ This means that notaries in Indonesia are obliged to change their way of working from conventional to digital.

The Notary Law uses the term of a cyber notary to show a notary's authority in certifying electronic transactions. According to Article 1 of the ITE Law, electronic transactions are legal actions using computers, computer networks, or other electronic media. All legal actions carried out using electronic media are electronic transactions. The legal actions consist of unilateral legal action committed by one party only and create rights and obligations. ${ }^{42}$ For instance, they are making a will as stated in Article 875 of the Civil Code and giving a gift for something stated in Article 1666 of the Civil Code.

Theodore Sedwick, the manager of the cyber notary Project-US Council for International Business, argues that the term cyber notary is used to describe a combination of the conventional notary-public function and its application in electronic transactions. A cyber notary can play a role in

41 Respati Nadia Putri, “Konsep Cyber Notary dalam Perubahan Undang-Undang Jabatan Notaris Sebagai Hasil Program Legalisasi Nasional” (2017), Thesis, Universitas Padjadjaran at 17.

42 C.S.T. Kansil, Pengantar Ilmu Hukum dan Tata Hukum Indonesia (Jakarta: Balai Pustaka, 2002) at 27. 
ensuring to parties in other countries when parties conducting transactions in a country are genuinely on their awareness and, without coercion or threat, has signed an electronic-based document. A cyber notary is likened to security in electronic transaction traffic via the internet. ${ }^{43}$ On the other hand, some argue that the term cyber notary was originally from the American Bar Association Information Security Committee's idea in 1994 by referring to some indicators. First, a trust when transacting between parties over the internet. Second, the security of transmission. Third, the integrity of the content of the communication. Fourth, the confidence that such transactions will receive legal recognition so that a binding contract is enforceable. In the context of the public key infrastructure, it connects the sender's private key with the receiver's public key under one umbrella trust. A cyber notary will authenticate documents electronically. Even a cyber notary is also expected to verify legal capacity and financial responsibility. There is a suggestion that the requirement should be an attorney.

This committee envisions a profession similar to a notary public (in the common law system). However, the documents in their hands are electronic-based. This profession's function is to strengthen the level of trust in a document. In this context, a cyber notary can authenticate electronic-based documents through electronic means where authentication can be printed out or verified immediately anywhere. Research conducted by Leslie Smith suggests that the term French electronic notary in the Trade Electronic Data Interchange System (TEDIS) legal workshop at the EDI Conference organized by the European Union in 1989 in Brussels. ${ }^{44}$ The essence is the existence of a party that presents an independent record of an electronic transaction conducted by the parties.

In terms of a cyber notary developed by legal experts using electronic media by teleconferencing, Edmon Makarim is a specialist in telematics. He pointed out a little to do with the cyber notary, identifying with the deed

43 Aldri Mandala Putra, "Akibat Hukum Bagi Notaris yang Mengiklankan Dirinya Melalui Website Ditinjau Dari Undang-Undang Nomor 30 Tahun 2004 Tentang Jabatan Notaris dan Kode Etik Notaris" (2012) Thesis, Universitas Indonesia at 53.

${ }^{44}$ Edmon Makarim, Notaris dan Transaksi Elektronik, Kajian Hukum tentang Cyber Notary atau Electronic Notary (Jakarta: Rajawali Pers, 2013) at 10. 
made through teleconference, but it is not. The working principle of a cyber notary is not much different from an ordinary notary in which the parties keep coming and dealing with the notaries. However, in this cyber notary, the parties immediately read the draft deed on their respective computers. After agreeing, the parties immediately signed the deed electronically at the notary's office. ${ }^{45}$ Thus, the notes are not made remotely using a webcam, but the parties physically meet the notary. The primary function of a cyber notary is to certify and authenticate electronic-based transactions. Certification refers to that notary is authorized to act as Certification Authority (Trusted Third Party), making them able to establish electronic-based certification to the concerned parties. On the other hand, authentication is related to legal aspects that should be completed during electronic-based transactions. ${ }^{46}$ Transactions conducted electronically are carried out in the indirect meeting between the parties, as it becomes prevalent in the deed making. It suggests that internet use can be very complex because it is more effective and efficient than ordinary conventional transactions.

There is an independent third party who records transactions between one party and another on an electronic basis in this context. An electronic notary is a notarization process or authentication of a signature on an electronic document through a particular method, which leads to the output in the form of a notarial deed that is generated or processed electronically. An electronic notary can vary from one country to another in practice, both procedurally, function, appointment, or the technology mechanism. It depends on the legal instruments governing it and the legal system adopted by the country concerned. ${ }^{47}$ Such robust evidence derives from the fact that notaries in civil law states have a formal obligation due to

45 Hukumonline, "INI Gembira Cyber Notary Masuk ke UU Jabatan Notaris" (2013), online: <https://www.hukumonline.com/berita/baca/lt52f6010370d79/ini-gembiracyber-notary-masuk-ke-uu-jabatan-notaris/ $>$.

46 Agung Fajar Matra, "Penerapan Cyber Notary di Indonesia Ditinjau dari UndangUndang Nomor 30 Tabun 2004 tentang Jabatan Notaris” (2012) Thesis, Universitas Indonesia at 58.

47 Hikmahanto Juwana, “Cyber Notary: Tantangan Bagi Notaris Indonesia” (2011), Seminar paper. 
the tabellionis officium fideliter exercebo principle. ${ }^{48}$ This obligation requires them to attend by themselves, see and listen to every single thing proposed in the deed establishment. Furthermore, they should also sign the deed and read the content in front of the proposers. The signature must be genuinely from the notary's and proposers' hands, not through an electronic-based system. This formal obligation has a powerful sense and benefit. It ensures that people who organize the agreement are those whose names are indeed mentioned in comparisons, not under pressure, imposture, or oversight. The agreement has corresponded to what the concerned parties want. Also, this obligation makes notaries responsible for what they have signed for a notary public and responsible for the content of the deed they have established. This idea is consistent with the regulation of authentic deeds based on Article 1867 of the Civil Code. It is perfect evidence as long as it is established in front of the notary public. ${ }^{49}$ Thus, the application of authentic deeds in electronic transactions can make the transacting parties safe and legal.

As the current development requires people to do everything electronically, the establishment of authentic deeds in Indonesia needs to be concerned, such as online-based credit applications. However, it remains some challenges. Although Financial Service Authority has controlled such applications, their actual practices do not use any authentic deed due to the limitation of using authentic deeds. Besides, an online-based agreement remains legally valid. It consists of several terms mentioned in Article 1320 of the Civil Code that agreement is considered valid when the concerned parties agree to engage themselves and their qualification to particular reasons and halal causes.

48 "Tabellionis Officium Fideliter Exercebo Principle" is a principle that states that notaries must work traditionally still maintained to this day. The notary practice is more to support maintaining the principle of tablelionis officium fideliter exercebo on the authentic deed. Grace Coresy and Moh Saleh, "Liability for Breach of Confidentiality Principles in Electronic Action If Connected to Law of Notary Service and Law of Electronic Information and Transaction" (2020) 9:7 Research Society and Development at 9.

49 Andes Willi Wijaya, supra note 31. 
Article 18 of the Notary Law mentions that notary has a functional area. It restricts online-based credit providers from implementing credit agreements through authentic deeds, as their debtors are Indonesian people. Then, the use of authentic deed remains absent in online-based credit applications since it opposes Article 1868 of the Civil Code that requires the deed to be established in notary's functional area and complete the terms mentioned in either relaas or partij deed. Regardless, an onlinebased credit agreement still needs an authentic deed as the only evidence with strong legal power. However, electronic-based documents are also considered legal evidence.

The Regulation of Financial Service Authority No. 77/POJK.01/2016 about Information-Technology-Based Credit Services (later called POJK) is another regulation about this issue. Article 19(1) mentions that the agreement of organizing information-technology-based credit services between executor and creditor is mentioned in an electronic-based document. Furthermore, Article 19(2) mentions that an electronic-based document should contain the number of agreements, the agreement's date, the identity of concerned parties, and stipulations of rights and obligations among parties. It should also consist of credit amount, rate of interest, commission, period, details of expense, the stipulation of fine, mechanism of conflict settlement, and settlement mechanism if the executor fails to continue their operational activities. According to those terms, the stipulations in POJK related to an electronic-based document for agreements are consistent with Article 1320 of the Civil Code. Although the agreement has completed all the terms and had legally valid evidence mentioned in the ITE Law, it still needs an authentic deed to become strong evidence for creditors. Moreover, Article 1868 of the Civil Code mentions that an authentic deed refers to a deed that form is under laws and regulations and established by or in front of an authorized official (a public official) and notary's functional area. This regulation indeed impedes the implementation of a cyber notary.

Consistent with this issue, authentic deeds in the digital era cannot be applied due to the basic principle of authentic deeds mentioned in Article 1868 of the Civil Code. This article contains several elements of an 
authentic deed. First, the deed is established under laws and regulations. Second, established in front of an authorized public official. Third, established in the notary's functional area. Although the ITE Law regulates digital signature that allows notaries to establish deeds through online media, it does not indicate that authentic deeds can be used in information-technology-based agreements. Article 11(1) of the ITE Law and Article 53(2) of Government Regulation 82/2012 on the Organization of Electronic System and Transaction mentions that digital signature has legal power and consequences as long as it completes several terms. ${ }^{50}$ This further assesses the possibility of doing the digital deed with various approaches, especially with legislation, such as the Civil Code, the Notary Law, and ITE Law.

The presence of digital signature supported by digital certification organized by the third party is a security system for digital information and communication. The use of digital signature indicates that digital information/document has complied with confidentiality, integrity, availability, authorization, authenticity, and non-repudiation since it was established, saved, proceeded, transferred, and accepted by another party through digital media. With certified digital signature, digitally signed electronic documents are undeniable among parties that deal with transactions equal to authentic deeds. In short, the authentication is technically secure, and the output automatically becomes authentic evidence. ${ }^{51}$ Certified digital signatures have a stronger legal standing than uncertified digital signatures. This means that digital signatures have the same standing as physical signatures in the eyes of the law.

50 They are (a) the data of making digital signature that only relates to the signatory, (b) the data of making digital signature only under the signatory's control, (c) any changes on digital signature afterward can be identified, (d) any changes of information related to digital signature afterward can be identified, and (e) the particular method is available to identify who the signatory is and to show that the signatory has agreed the concerned digital information.

51 Hukumonline, "Layanan Notaris Secara Elektronik dalam Kedaruratan Kesehatan Masyarakat" (2020), online: <https://www.hukumonline.com/berita/baca/lt5e968b0 8889e7/layanan-notaris-secara-elektronik-dalam-kedaruratan-kesehatanmasyarakat-oleh--edmon-makarim?page $=4>$. 
There is a relationship between the notarial function and the ITE Law's aim and signing the deed mentioned in the entire electronic-based transaction statement. It is considered as a deed whose verification is similar to an authentic deed. Its implication is on its verification of the digital signature. The implementation of the digital signature may also be applied in Indonesia. Still, it has not been accomplished on legal securities because its verification cannot shift from electronic documents to authentic ones, although the documents are private deeds. Based on Article 1320 of the Civil Code, the legalization of e-commerce is valid. The alliance conducted electronically through electronic intermediaries in the form of alliances conducted freely, either written or oral, has been done as stipulated in Article 1320 of the Civil Code. Then, implementing digital services happens due to any formal terms that should be completed for the sake of legality. Those formal terms involve: (a) established in front of an authorized public official; (b) attended by concerned parties; (c) both concerned parties are recognized by or introduced to the notary, and (d) attended by two witnesses. These four terms are cumulative. Once it fails to complete one of the terms, the deed is considered formally default. ${ }^{52} \mathrm{In}$ terms of business needs require speed and accuracy to be an urgency that must be considered. However, the authentic nature of a notary deed must still be maintained. Normatively the concept of cyber notary has not been accommodated in Notary Law.

This problem relates to the notary's obligation to the deed. Article 16(1) of the Notary Law regulates attaching the document and the proposers' fingermark on the deed's original and reading the deed in front of the proposers. Also, it should be attended by two witnesses or four witnesses in particular to the private deed of will and signed at the same time by the proposers, witnesses, and notary. The purpose of this regulation should be expanded on behalf of the e-notary. Edmon argues that the classic problem of e-notary is the norm of physical attendance in the deed establishment,

52 Udin Nasrudin, "Urgensi E-Notary di saat Pandemi, Pergolakan antara Kepastian Hukum dengan Kemanfaatan Hukum" (2020), online: <https://kliklegal.com/urgensie-notary-di-saat-pandemi-pergolakan-antara-kepastian-hukum-dengankemanfaatan-hukum/>. 
not through an electronic-based system. It is a must for concerned parties to physically attend and sign and give fingermark on the deed's original, as mentioned in the Notary Law. Ignoring this absolute term may bring legal consequences for a notary.

On the other hand, Article 5(1) of the ITE Law mentions that digital information or document or copy is legally valid evidence. However, Article 5(4) mentions that any stipulation related to electronic-based information does not apply to documents that should be made according to laws and regulations black-and-white and in the form of the notarial deed by an authorized public official. Hence, a cyber notary for digital deed is currently unable to apply because it needs consistent legal protection. Mainly, it deals with the part of notarial regulation to make them able to serve people in both conventional and digital ways, especially in establishing electronicbased authentic deeds. ${ }^{53}$ As an alternative, Indonesia (as civil law state) may independently define a cyber notary and apply several borders of using technology for the deed legality and keep it consistent with the notary's essential spirit as a public official. As it has been applied in Georgia, the electronization does not abolish their obligation to meet the notary. In this case, the notary definition is expanded through which the concerned parties do not have to see the same notary. They only have to meet a notary in their domicile area to establish the agreement through video conference. This example confirms that a cyber notary in civil law state will not remove a notary's obligation to uphold his tradition to maintain the legality of the deed he established. ${ }^{54}$ Thus, in the common law system, a cyber notary can be widely applied differently in civil law system countries because of the difference in legal characteristics, especially in this case, the difference in the notary legal system between the two jurisdictions.

The application of electronization can also be made in Indonesia, but it cannot oppose an essential letter. It is because the proof of the deed's validity is at the stage of ratification that it is not easy to do to convert documents of electronic nature into an authentic deed. By referring to

53 E. Nurita, Cyber Notary (Palembang: Refika Aditama, 2012).

54 Andes Willi Wijaya, supra note 31. 
Article 1320 of the Civil Code, the legalization of e-commerce can be done and valid due to the absence of a limit to conducting alliances face-to-face in that article. However, it can be done indirectly or online through electronic media intermediaries because it fulfills the terms of the agreement as outlined in the Civil Code. Simultaneously, the Notary Law states that the authentic deed must be done before public officials, i.e., a notary public. Therefore, notary requires regulations governing the authority to create digital deeds. This digital deed can be done in an electronic notary system, and the notary is granted authority on electronic signatures as stated in the ITE Law. It does not negate the obligation of the parties to appear before a notary public because the deed is done without a notary public's role and the transaction is considered to have no power before the law.

\section{CONCLUSION}

As many online-based professions grow, a cyber notary in Indonesia should be well prepared by considering several matters such as working system, technical procedures, infrastructure, and resources as legal protection that should be consistent with the other ones. Then, the use of authentic deeds requires a digital way, which needs to be the government's concern. Based on the existing regulations, any authentic deed established by a notary cannot be applied through an electronic-based document due to the clash of stipulations among the Civil Code, the ITE Law, and the Notary Law. For instance, online credit applications need a notary as the third party to establish a credit agreement. However, such applications remain using private deed for their credit agreement, although Financial Service Authority has constantly monitored them. The use of authentic deed needs to be mentioned in online-based credit applications for protecting creditors and debtors. However, Indonesia restricts it under the ITE Law. Some ITE Law provisions are not consistent with the Notary Law and the other laws and regulations in dealing with a cyber notary. 


\section{ACKNOWLEDGMENTS}

None.

\section{COMPETING INTERESTS}

The authors declared that they have no competing interests.

\section{REFERENCES}

A.A.Andi Prajitno, Seri A Kewenangan Notaris dan Contoh Bentuk Akta (Perwira Media Nusantara, 2018).

Abdul Ghofur Anshori, Lembaga Kenotariatan Indonesia Perspektif Hukum dan Etika (Yogyakarta: UII Press, 2016).

Agung Fajar Matra, "Penerapan Cyber Notary di Indonesia Ditinjau dari Undang-Undang Nomor 30 Tahun 2004 tentang Jabatan Notaris" (2012) Thesis, Universitas Indonesia.

Aldri Mandala Putra, "Akibat Hukum Bagi Notaris yang Mengiklankan Dirinya Melalui Website Ditinjau Dari Undang-Undang Nomor 30 Tahun 2004 Tentang Jabatan Notaris dan Kode Etik Notaris" (2012) Thesis, Universitas Indonesia.

Andes Willi Wijaya, "Konsep Dasar Cyber Notary : Keabsahan Akta dalam Bentuk Elektronik" (2018), online: <https://vivajusticia.law. ugm.ac.id/2018/11/29/konsep-dasar-cyber-notary-keabsahan-aktadalam-bentuk-elektronik/>.

Bambang Pratama, "Perubahan Dan Tantangan Hukum Menghadapi Industri 4.0" (2018), online: <https://business-law.binus.ac.id/2018/ 07/07/perubahan-dan-tantangan-hukum-menghadapi-industri-4-0/>.

Busyra Azheri, "Tantangan Pendidikan Kenotariatan di Era Revolusi Industri 4.0” (2019) Magister Kenotariatan, Universitas Sumatera Utara. 
C.S.T. Kansil, Pengantar Ilmu Hukum dan Tata Hukum Indonesia (Jakarta: Balai Pustaka, 2002).

Daeng Naja, Teknik Pembuatan Akta (Yogyakarta: Pustaka Yustisia, 2012).

Edmon Makarim, Notaris dan Transaksi Elektronik, Kajian Hukum tentang Cyber Notary atau Electronic Notary (Jakarta: Rajawali Pers, 2013).

E. Nurita, Cyber Notary (Palembang: Refika Aditama, 2012).

G.H.S. Lumban Tobing, Peraturan Jabatan Notaris (Jakarta: Erlangga, 1991).

Global Regulation, Ordinance for Enforcement of the Notary Act, online: $<$ https://www.global-regulation.com/law/japan/277686/ordinancefor-enforcement-of-the-notary-act.html>.

Grace Coresy and Moh Saleh, "Liability for Breach of Confidentiality Principles in Electronic Action If Connected to Law of Notary Service and Law of Electronic Information and Transaction" (2020) 9:7 Research Society and Development.

Habib Adjie, Aspek Pertanggungjawaban Notaris dalam Pembuatan Akta (Bandung: Mandar Maju, 2011).

Habib Adjie, Kebatalan dan Pembatalan Akta Notaris (Refika Aditama: Bandung, 2015).

Habib Adjie, Hukum Notariat di Indonesia-Tafsiran Tematik Terhadap UU No.30 Tahun 2004 Tentang Jabatan Notaris (Bandung: Refika Aditama, 2008).

Habib Adjie, Hukum Notaris Indonesia (Jakarta: Refika Aditama, 2007).

Herlien Budiono, Dasar Teknik Pembuatan Akta Notaris (Bandung: Citra Aditya Bakti, 2017).

Herlien Budiono, "Kumpulan Tulisan Hukum Perdata di Bidang Kenotariatan” (Bandung: Citra Aditya Bakti, 2008). 
Hikmahanto Juwana, "Cyber Notary: Tantangan Bagi Notaris Indonesia" (2011), Seminar paper.

Hukumonline, "INI Gembira Cyber Notary Masuk ke UU Jabatan Notaris" (2013), online: <https://www.hukumonline.com/berita/baca/ lt52f6010370d79/ini-gembira-cyber-notary-masuk-ke-uu-jabatannotaris/>.

Hukumonline, "Layanan Notaris Secara Elektronik dalam Kedaruratan Kesehatan Masyarakat" (2020), online: <https://www.hukumonline. com/berita/baca/lt5e968b0 8889e7/layanan-notaris-secara-elektronikdalam-kedaruratan-kesehatan-masyarakat-oleh--edmonmakarim?page $=4>$.

Indra Pranajaya, "Studi Komparatif Terhadap jabatan dan kode etik notaris di Indonesia dan Jepang" (2012) Thesis, Universitas Indonesia.

Irma Devita, "Menyongsong Kongres Notaris International," 2019, online: $<$ https://irmadevita.com/2019/menyongsong-kongres-internationaldunia-notaris/>.

Lumbuan Tobing, Peraturan Jabatan Notaris (Jakarta: Erlangga, 1983).

Luthvi Febryka Nola, "Peluang Penerapan Cyber Notary dalam Peraturan Perundang-undangan di Indonesia” (2011) 2:2 Jurnal Negara Hukum.

Meriam Darus Badrulzaman, "Mendambakam Kelahiran Hukum Saiber (Cyber Law) di Indonesia" Speech of Professorship Retirement (Medan: Universitas Sumatera Utara, 2007).

M. Ali Boediarto, Kompilasi Kaidah Hukum Putusan Mahkamah Agung, Hukum Acara Perdata Setengah Abad (Jakarta: Swa Justitia, Jakarta, 2005).

M. Rustam, "Internet dan Penggunaannya ((Survei di Kalangan Masyarakat Kabupaten Takalar Provinsi Sulawesi Selatan” (2017) Jurnal Studi Komunikasi dan Media.

Naily Zahrotun Nisa, "Aspek Legalitas Penyimpanan Minuta Akta Notaris Secara Elektronik” (2020) 5:2 Jurnal Civic Hukum. 
Peter Mahmud Marzuki, Penelitian Hukum (Jakarta: Kencana Prenada Media Group, 2011).

Ratih Tri Jayanati, "Perlindungan Hukum Notaris dalam Kaitannya dengan Akta Yang Dibuatnya Manakala Ada Sengketa di Pengadilan Negeri” (2020) Thesis, Universitas Diponegoro.

Respati Nadia Putri, "Konsep Cyber Notary dalam Perubahan UndangUndang Jabatan Notaris Sebagai Hasil Program Legalisasi Nasional” (2017), Thesis, Universitas Padjadjaran.

Sjaifurrachman, Aspek Pertanggungjawaban Notaris dalam pembuatan Akta (Bandung: Mandar Maju, 2011).

Udin Nasrudin, "Urgensi E-Notary di saat Pandemi, Pergolakan antara Kepastian Hukum dengan Kemanfaatan Hukum" (2020), online: $<$ https://kliklegal.com/urgensi-e-notary-di-saat-pandemi-pergolakanantara-kepastian-hukum-dengan-kemanfaatan-hukum/>.

Wijanarko Fahma Rahman, "Tinjauan Yuridis Akta Notaris Terhadap Pemberlakuan Cyber Notary Di Indonesia Menurut Undang-Undang Nomor 2 Tahun 2004" (2015) 2:2 Jurnal Repertorium.

Zainatun Rossalina, Moh Bakri, Itta Andrijani, "Keabsahan Akta Notaris Yang Menggunakan Cyber Notary Sebagai Akta Otentik" (2016) Magister Ilmu Hukum dan Kenotariatan. 